\title{
VALUE DEVELOPMENT IN HISTORY LEARNING THROUGH PARIBASA AND BABASAN
}

\author{
Agus Mulyana ${ }^{1}$ \\ Wawan Darmawan' \\ Yeni Kurniawati ${ }^{3}$
}

\begin{abstract}
This research derived from an anxiety that looked history learning as a subject that was very close with intellectual competences development. In fact, history itself ilustrated value experience which could give such a kind of wisdom, and more over the history also had a big value in it. So, it was thought that there was a need to have a right strategy to understand the value of history. One kind of value that could be internalized to students in history learning was Sundane local wisdom. Sundanese culture had various inheritances, for example was like oral literature (folklore) in paribasa and babasan. The problems in this research were how to identify the values of Sundanese culture in paribasa and babasan, and how the people could use paribasa and babasan in a process of value socialization and internalization, how those values could be applied in history learning. This research used a qualitative approach. It was divided in two phases, the first one was about folklore, and the second one was about naturalistic study on history learning process in the class. The result of this research was also divided in two parts. The first part was related to social values identification that could be extracted on Cireundeu Cultural Village pass through paribasa and babasan. Based on the result of the observation and interview with the villagers, they used paribasa and babasan which generally got the same point with the others Sundanese societies, so there was no specialty in Cireundeu. The main point was they still used paribasa and babasan in their daily life, especially when they counseled their children, interacted to each other, said euphemism critic, and taught Sundanese values to the young generations. Second, this part was related to paribasa and babasan's value implementation in history learning on SMA Pasundan 1 Bandung. There were two approaches in this implementation, value inculcation approach and value clarification approach. This kind of history learning that put paribasa and babasan as a media of value inculcation passed through appreciation, self-identification, behavior implementation, and habit forming .
\end{abstract}

Key words: Babasan, paribasa, value, history learning

\footnotetext{
${ }^{1}$ Agus Mulyana, lecturer of History Education, Faculty of Social Science Education, Indonesia University of Education. For academic interest, the author can be contacted at email: agus_mulyana_upi@yahoo.com.

${ }^{2}$ Wawan Darmawan, lecturer of History Education, Faculty of Social Science Education, Indonesia University of Education. For academic interest, the author can be contacted at email: walin_history@yahoo. co.id.

${ }^{3}$ Yeni Kurniawati, lecturer of History Education, Faculty of Social Science Education, Indonesia University of Education. For academic interest, the author can be contacted at email: yenikurniawati72@ yahoo.com.
} 


\section{Introduction}

History education in school is still close to intellectual competences (cognitive) that forms in fact memories as a main goal. On the other hands, the affective aspect is being abandoned. It makes a strong assumption that history learning is only for committing memories and facts. This point of view is believed because history is well-known as boring subject, the students are not interested with it, and they think learning history has no advantage for them. Nowadays, it will be not enough if we only have intellectual competences, but also we need to be stubborn, and have tenacity, devotion, and social interaction skills; that's why history education in school need to be more aware to affective aspect and based value education.

As Abdulah (1999) implied, history keeps worth experiences which can give wisdom and more over the history also has a big value in it (Wiriaatmadja, 2002: 149). With using the right strategy in understanding the history values, history learning can heighten up the critical thinking and creativity of a nation, especially to face the challenges. This kind of history teaching, recognized by experts, has a role in regenerate the nation's values strengthen the goal of education.

One kind of values that can be internalized to students in history learning is Sundanese local wisdom. Sundanese culture has various inheritances, for example, is oral literature (folklore). Those traditional idioms contain so many teachings, counseling, and norms that happen in the society. Folklore can be used as an analyzing tool to know the collective behavior; because folklore itself reveals how its developes thought.
One of the traditional oral expressions in society is paribasa and babasan Sunda. In etnopedagogy perspective, local wisdom such as paribasa and babasan can become a source of learning innovation that can be used; including empowered to address a variety of issues contained in the lesson. Paribasa and babasan are idioms that are used to summarize Sundanese long story and be compiled into standard sentence containing advice, proverbs, and other expressions that characterizes the local language. Its structure is made by Sundanese ancestors and contains certain meaning. Order in relatively fixed words, because if there is a change it will change the meaning or significance as well.

A review of Rusyana (1982:3), states that paribasa divided into three parts, the invitation to do good, forbid wrongdoing, and experience". From other studies, Rosidi (2005:11-12)revealedthatparibasaessentially shows us warnings about what do not do something that is not commendable or pose a dangerous, and suggest things that should be done by people. Paribasa and babasan reflects good values in Sundanese belief: istikomah, faithful, humble, interpersonal ability, responsible, and negative values as treasonous, arrogant, pond of fighting, talk without content, spiteful, pleased with the misfortune of others, and other shameless behavior (Rosidi, 2005: 11).

The problem now is how to identify Sundanese values in paribasa and babasan. After it, the problem is how to asses then those values' validation in the society and how the values can be internalized and socialized to the society. Once these things get, these values can be applied in a contextual history learning through forming the character are ready to face the challenges that they will face in the modern era. 


\section{Methods}

This research used a qualitative approach. qualitative research methods, was defined by Bogdan and Taylor (1982:1-2) who said qualitative research methods as a research procedure that produces descriptive data in the form of words-written or spoken of and behaviors that can be observed. thus, as this study used a qualitative approach, the qualitative measures are performed consistently. it means that, this study does not use mathematical calculations and statistical but rather emphasizes the interpretive study.

It was based on Creswells (1998: 1) opinion that describes the purpose of qualitative research is to understand the problems of humanity or society, based on the preparation of a complex and holistic picture of the view of the details of the informants, and conducted in scientific. A qualitative approach emphasizes the meaning understanding (verstehen), and reasoning of the definition in a particular situation (in certain contexts), more research matters related to daily life and fundamentally depended on observations in humans in its own region, and related to these people in the language and terms (Creswell, 1998: 2, Moleong, 2006: 2).

it was divided in two phases, the first one was about folklore, and the second one was about naturalistic study on history learning process in the class. folklore research was also divided in three steps: collecting, classifying, and analyzing. Danadjaya (Bungin, 2008: 114) has formulated the stages that must be passed by the researchers: (a) preresearch phase, (b) a real research phase, and (c) how to make a script for archiving folklore. once the researchers were able to collect and identify paribasa and babasan, the next step in the learning process was implemented in history learning. In this activity, researchers used a naturalistic inquiry approach model of lincoln and guba. this study used a naturalistic inquiry approach of Lincoln and Guba models, and researchers acted as an instrument. Simply, naturalistic inquiry can be defined as an inquiry that can be done in the natural settings using natural methods as well (Aliasar, 1998: 4).

Researchers observed, browsed, and watched the efforts in history learning impemented through using paribasa and babasan as the value inculcation media. Target or object in this research was restricted, so the data can be majorly gained, as well as for preventing from widening the object. Therefore, the credibility of the researchers alone determined the quality of the research (Bungin, 2001: 26). Lincoln and Guba (1985: 39), prefer to use the term Naturalistic Inquiry because of the prominent features of this research are observation and data collection that could be done in the natural setting or background, it means that is without manipulating the subject itself (as in the nature). With this approach, researchers would record process of understanding, appreciate self-identification, apply for values in behavior, and also watch the habit forming that appeared in the students in the history learning process used paribasa babasan as value inculcation media.

This qualitative research held on Cireundeu Cultural Village, and its learning value and principles were applied to SMA Pasundan 1 Bandung. The following reasons of choosing Cireunde as the site of the research were: 
1. based on pre-research phase,Cireundeu's villagers still used paribasa and babasan idiom in their daily interaction

2. The active bearers are still lingered

3. Cireundeu's villager still believed in the values that contained paribasa and babasan

4. Paribasa dan babasan in Cireundeu had not much studied yet by the other researchers.

Meanwhile, reason of choosing SMA Pasundan 1 Bandung was because this school wanted to make the value of Sundanese culture as the education base on SMA Pasundan 1 Bandung. This similarity vision between school and researchers who made research agreed to make this school as a site of research. Subjects on the research were Sundanese paribasa and babasan of Cireundeu Cultural Village's society, teachers of SMA Pasundan 1 Bandung, and students of 1oth class of SMA Pasundan 1 Bandung on history subject by the 2012/2013 academic year.

\section{Results}

The result of this research can be divided in two parts. The first part is related to social values identification that can be extracted on Cireundeu Cultural Village through paribasa and babasan. Second part is related to paribasa and babasan's values implementation in history learning in SMA Pasundan 1 Bandung.

\section{Social-Cultural Values on Cireundeu Cutural Village's Society}

The study was based on Cireundeu's geographical location. Culture area conception is a right concept that can represent the condition in Cireundeu. Culture area is a region that has some characteristics of culture and some of specified complexity (Banks, 1990: 274). A 'culture area' has a relation with the culture development that caused appearance of new elements which can push the old elements to the side of the region.

Administratively, Cireundeu Cultural Village is located on Leuwigajah District, Sub-District of South Cimahi, Cimahi City. The distance between Cireundeu and Leuwigajah District is about 3 kilometers, 4 kilometers lenght to Sub-District of South Cimahi, and 6 kilometers to Cimahi City. The topography condition is flat, wavy, and downy. It is bordered by Batujajar Sub-District on West Bandung Regency. This village is also located on a valley of Kunci Mountain, Cimenteng Mountain, and Gajahlangu Mountain. It has 50 head families and 800 people. Cireundeu Cultural Village area is 64 hectares, 60 hectares is for farming and 4 hectares is for residence.

A kind of local genius on Cireundeu's society is about their belief which is called as Sunda Wiwitan. Sunda Wiwitan doesn't mean as a religion for worshiping, but religion that has values which have to be applied in daily life. That's why the society in Cireundeu still keeps their traditions and worshiping site that is still very rare to be found.

Cassava is the main food in Cireundeu. This main food was messaged by the ancestors since 1924. The ancestors worried about food scarce that would happen later, and this message had appeared since Madrais, a local figure, was arrested by The Dutch and didn't have rice for three months 
(based on interview with Abah Emen, July 29th 2012). Since that, Cireundeu became a village that its society left rice and didn't depend on it as the main daily food. Cassava was proved could save Cireundeu's society from food scarce. Until now, there is no lack of food in Cireundeu. Cassava in Cireunde can be made as so many types of food, it can be made as a model of food endurance program in the other villages.

Cassava planting in Cireundeugenerally has become a habit for the society. It started with land managing, planting, maintaining, harvesting, and food making. The most popular food in Cireundeu is rasi. Rasi means beras-singkong (rice-cassava). It is done since 80 years ago as a daily activity in Cireundeu until now. Cireundeu village can be declared as a self village in the food aspect, and the fluctuation of rice price will not effect Cireundeu.

There are some meanings of sampeu (cassava) conception on society of Cireundeu Cultural Village. Those meaning are, from the functionalism theory point of view, the tradition of making cassava as a meal is a tradition to make solidarity. Implied to Brown (1952), that making rice as a taboo thing and making cassava as a compulsory will strengthen and keep the important values in the society (Parry, 1081).

Sampeu conception can be studied as a semiotic symbol. Semiotic study is a study of symbols which positioning symbols as a system in a certain context of a constant, stable, and unchanged time (Pialang, 2003: 45). Sampeu, looked by Saussure's point of view, is as an abstraction of certain cultural symbol in a system, so it means that all of the thing that exist in human life can be said also as symbols which have to be meant. (Van Zoest, in Suddjiman and Van Zoest, 1992: 2). Symbols which have structure are the meaning process of relation between signs and a structure result of process in human cognitive aspect. In Sausure's theory, 'significant' is not a language concrete sound, but it is about image accoustique. What is lied in human life can be seen as something which has a certain form and meaning. Still on the Saussure's theory, that there is no impersonal relationship between form and meaning, but as a social relationship, both that based on social convention (Hoed, 2011: 3).

From the perpective of Geartz, culture basically represents the meaning of system and the value system. From the aspect of cognitive approach of culture, it is trust system or conducive knowledge follower of the culture who see its world, society, and his self. From approach of Geartz the with pursuant to result of interview with abah Emen (29 July 2012), can be conclued that philosophy values of cassava is effort draw near x'self with the creator (eling ka pangeran). Besides, cassava is a people character manifestation of sunda the act of adigung adiguna (don't bluff), cul dogdog tinggal igeul (spirit lose) and tjati kasilih ku junti and also mustika leungit tinggal bungaok. Cassava make Kampong society of Cireundeu feel the independence of the bearing mind (merdeka lahir batin), selfsupporting and not depended on others.

The change of time and its challenges actually has been estimated. Changing is something that can't be avoided. Because of that, as a supply to face the challenges in modern era, there is a need for local culture 
to be as a moral guidance in society's daily life behavior. The values can be formed as a slogan, counsel, or idiom that spread mouth to mouth. Then by direct and indirect, it can be made as a guidance or measure to evaluate some acts or behaviors that occur on society or bureaucracy.

The examples of traditional oral idiom that linger in Sundanese society, include in Cireundeu Cultural Village, are paribasa and babasan. Paribasa and babasan are idioms that have conotative contains, not the real meaning actually, and those can be ordered by part of bodies, things, behaviors and characteristics of human, animal, or plants. Paribasa and babasan represent the feelings or thought that should be sent to the other people. Based on observation and interview in Cireundeu Cultural Village, paribasa and babasan are generally used just between Sundanese people. The main point is they still use paribasa and babasan in their daily life, especially in counseling their children, interacting with each other, saying a kind euphemism critic, and teching Sundanese values to the young generations.

Cireudeu's society uses paribasa and babasan to explain Sundanese charactheristic, for some examples: ulah adigung adiguna (don't be arrogant), cul dogdog tinggal igeul (don't lose yourself) dan jati kasilih ku junti (home defeated by visitor) and leungit mustika tinggal bungaok, cageur, bageur, bener, pinter, siger tengah, leuleus jeujeur, liat tali, laukna beunang caina herang, bengkung ngariung bongkok ngaronyok, tiis ceuli, herang panon, landung kandungan laer aisan, pindah cai pindah tampian, kawas kujang, teu adigung kamagungan (don't be egoistic); sacangreud pageuh, sagolek pangkek, henteu ganti pileumpangan (keep standing on your faith); leber wawanen (full of encourage), kudu boga pikir rangkepan (beware); kudu jadi gunung pananggeuhan (should be the mainstay of the people).

The messages on paribasa and babasan firstly just for Sundanese people, now become such as universal messages for everyone exclude the Sundanese people. It makes the people more aware to keep the relationship between human and environment. Every life community, includes humankind, needs a kind of equality and harmony in their life.

\section{Implementation of Paribasa dan Babasan in History Learning}

Sharma (2008: 29) reveals that most often values that be taught in history learning are cultural values. Sleeter (1996) suggestsseveralapproachestomulticultural education, one of that is teaching the culturally different approach and Human Relation Approach. This approach seeks to improve the academic skills of students by providing relevant learning with the embraced culture by students. Human Relations Approach; students are taught about the togetherness which includes an understanding of the social and cultural differences.

Oneofthevaluesthatcanbeinternalized to students in history learning are the values of Sundanese culture local wisdom. One of the traditional oral expressions in society is paribasa and babasan Sunda. In etnopedagogy perspective, local wisdom such as paribasa and babasan can become a source of learning innovation that can be used; including empowered to address a variety of issues contained in the lesson. 
Learning process that had been planned by the researchers used two kinds of aproaches: value inculcation approach and value clarification approach.

\section{Value Inculcation Approach}

Value inculcation approach is an approach that emphasizes the social values inculcation in students. According Superka et al. (1976), the purpose of education according to the value of this approach are: first, the receipt of certain social values by students; and second, changes in the values of students who do not conform to social values desired. The methods used in the learning process according to this approach include: exemplary, positive and negative reinforcement, simulations, games, role, etc. (Elmubarok, 2008: 61).

This approach is a traditional approach. There are so many critics in many literatures towards this approach. This approach is seen an indoctrination, and not appropriate with democracy life (Banks, 1985; Windmiller, 1976). This inculcation approach maybe doesn't fit to the individually western life, but as Superka et al. (1976) revealed, realized or not, this approach is used widely in society, especially in inculcation of religious and cultural values.

Inculcation approach implemented in history learning through using paribasa and babasan, done by the teachers with related the history contents with the relevant paribasa and babasan. Furthermore, teachers explained the values in paribasa and babasan as an oral tradition on prehistoric era discussion. This type of learning used to motivate the students also.

\section{Values Clarification Approach}

Values clarification approach (VCT) emphasized the students to inquire their own feeling and behavior, to increase their consciousness about their own values (Elmubarok, 2008: 70). VCT was developed by Louis Rath, Merril Harmin and Sidney B. Simon, and this model was designed to support the options of intelligent values though the process of 'choosing', 'prizing', and 'behaving'. Students choose their favorite, prize the priority, and behave accordingly to the priority based on their favorite things (Hakam, 2000: 187).

There were three goals of this approach. First, to help students to be more aware and to identify their own and the others' values. Second, to help student to have an open and honest communication that relates to the values. Third, to help students to use the logic thoughts and emotional consciousness to understand their affection, values, and behavior (Superka, et al 1976). In teaching process, this approach used dialogue methods, writing, discussion in big and small groups, and etc. (Raths, et al. 1978; Elmubarok, 2008: 70). Target of this VCT were to help students to decrease students' value confusion and to develop a consistent value system. The value system would like to be a base to make a choice. Through the valuing process, students were mixed up with their affections and values which made them able to make a consistent choice and informed accurately (Hakam, 2000: 188).

This approach emphasizes the real value owned by an individual based on their own experience and variety of backgrounds, not determined by external factors, such as religion, society and so on. Therefore, for 
the adherents of this approach, the content value is not too important. It is sometime overlooked too in the education program, that is to develop students' skills in the process of judging. Consistent with that view, as represented described by Elias (1989; Elmubarok, 2008: 71) that the adherents of this approach, the teacher is not teaching values, but as a role model and driving. The role of the teacher is to encourage students with questions that are relevant to developing students' skills in conducting a process of assessing (Elmubarok, 2008: 71).

The main difficulty that the teachers have in using this model is 'students are free to choose the values they hold; even those completely analyze each alternative before choosing'. Unlike the model of jurisprudence, there are no established standards or principles to evaluate opposing values; each student is free to determine its own value. Through the process of asking, track and other analytical processes the VCT authors expects students not only clarify their values but also do a lot of opposition to human values and social values that have been received (Hakam, 2000: 187).

Forms of value analysis approach adopted in the history teaching in SMA Pasundan 1 Bandung were implemented as follows:

1. students were given space to assess and choose the suitable paribasa and babasa so that they could hold onto in daily life;

2. students were given the space to criticize the values in paribasa and babasan, even to disagree with it;

3. students were given the task to find paribasa and babasan that commonly used in daily life at their home, so the student were expected also to be better in integrating the values that have been clarified into their daily life.

\section{Analysis of the Values Education and History Teaching Implementation Through Paribasa and Babasan}

The implementation of history teaching that used paribasa and babasan in the value inculcation media were as follows.

\section{Understanding}

Paribasa and babasan are part of the tradition and culture of Sunda. Tradition is a pattern of behavior or beliefs that have become part of a culture that has long been known from generation to generation (Soekanto, 1993: 520). Students need to learn the traditions, because the study of traditions contain values of high nobility and untouched by religion and global culture. History teaching, by Bining and Bining (in Wiriaatmadja, 2002: 260), aims to train and discipline students' minds, provide moral and religious education, and instill awareness of nationalism and patriotism, good citizenship, even for recreation.

Understanding of the values contained in paribasa and babasan is the first step to be a base for the other stages. Without the aspect of understanding, it will be difficult for other measures developed in a learning process (Hasan, 1996: 251). If students do not know paribasa and babasan including the value contained in it, then they will not be able to develop the attitudes towards the value. This is the initial resistance of the study. As revealed from the initial questionnaires and observation, nearly $50 \%$ of students do not understand and know paribasa and babasan. Their response when they heard paribasa and babasan 
was laughing because they thought as something strange and funny.

However, it does not mean this research should be stopped and the teachers just give up developing value in learning. On the contrary, the problem was encouraging teachers to develop values paribasa and babasan as the value of education. It is something that very essential in history teaching and learning. Students' understanding of the importance of values in the teaching of history can be analyzed as follows:

First, almost all of the students argued that the educational value of history learning is important as a way of life, in the way of limiting both good and bad behavior, balancing in order not to deviate, forming good habits, a better understanding of the culture and positive morale, selfintrospection, and give inspiration. Thus, teachers did not need to worry to teach values such as those proposed by Fraenkel (1977: 3-5) who points out there are some things that lead teachers in the U.S. do not involve the value of the teaching-learning process, namely: the majority of teachers in the U.S. grew in traditional culture view that question the value as much on less taboo to be discussed in public because its value is very private and often talk about the value of such in the school with the parents even cause a lot of controversy. Second, students look at the value stratification and assumed that certain the value higher than the other. Students who maintain religious values are higher than the ones who maintain cultural values, so cultural values should be adjusted to the religious value. Quite a lot of students also assess in terms of the value emergence. Nevertheless, most students viewed the value in the parallel position. Third, tstudents who wanted to study history because of score-oriented, but there are also students who wanted to study the value of history learning but not necessary depth because they are afraid of overlapping with religious and government subjects.

Various students' opinions can be concluded that the students are able to get and understand the values contained in paribasa and babasan: the civility values, religious values, morals, and full of advice. But from the students' responses, researchers could conclude a few things that cause them not accept the using of paribasa and babasan including values contained becouse of the following reason:

a pond of with the external habit

b embarrassed to use it because it is very traditional Sundanese culture

c must be measured with less religious values

d Sundanese tradition is not fit to modern people, and impressed plebeian

\section{Aprreciating}

Hasan (1996) and Hakam (2000) implied, an individual would appeciate the values after they understood, satistied, felt proud of it. In a process of appreciating, an individu revealed his or her choices to the public, and they didn't feel embarase with it. School is an education media that need to be encouraged for making their students to appreciate the society's culture better. Holmes Group (1990: 22) pointed: "schools need to become bridges between the mainstream culture and the lives and culture of their students".

Students appreciation to paribasa and babasan could be seen from several 
indicators. First, students showed a positive attitude based on rational reasons, subjective, and emotional values of Cireundeu society that contained in paribasa and babasan. Based on the results of previous studies, the majority of students accepted and appreciated the contained values in paribasa and babasan, but many of them were also embarrassed to use it in daily life as it seemed cheesy, traditional, not modern, and they only liked foreign culture. Based on those indicators, students were divided into two categories: students who showed positive attitudes and students who showed negative attitudes for reasons already stated above. Second, students had a desire to develop the values of Cireundeu society that contained in paribasa and babasan as part of their personality. Third, students discovered the benefits from Cireundeu's society and values contained in paribasa and babasan. In addition, the students realized the losses for themselves, groups, and communities if they can't implement the Cireundeu's society values and the valuess of paribasa and babasan.

\section{Self Identification}

Indicator of self identification process was students could relate the values of paribasa and babasan with their own daily life. It meant that the contained values on paribasa and babasan steped by steped had become their personality in the begining phase. After three months of being close with paribasa and babasan values, student could choose some values to be held for their life:

a keep learning from the past, keep practicing, and be humble

b keep thinking that everyday is the last day in life c the most important thing is religious value

d there is always sky above the sky, never under estimate the others

e believe in God, appreciating each other with morals

f never be afraid, don't run from your problem, do everything have to has value guidance

\section{Behavior Implementation and Habit Forming}

Long before they were acquainted with paribasa and babasan in history learning, paribasa and babasan have used to use in their daily life. For examples burukburuk papan jati (althrough bad, they still your family), hampang birit (obey to parents), indung tunggul rahayu, bapak tanggal darajat (respect own parents), ku keyueng tangtu pareng, amis budi, hirup ulah manggih tungtung, paeh ulah taya beja, ka cai jadi saleuw, ka darat jadi saleubak, adat kakurung ku iga, hulu gundul dihihidan (lucky man get who gets more lucky things), ambeuk sadu santa budi (must be a religious person), elmu angklung, kudu silih asah, silih asih, silih asuh, handap asor, ngadu angklung (rude debate), kawas anjing jeung ucing, jeung lewehmah mending waleh, legok tapak genteng kadek, muray bulu hiris (doesn't comfort in home), ulah ngaliarkeun tales atuel (don't spread any backstabbing), kudu bisa kabulu kabala (have to adapt), ngaduk cikur kedah mihatur nokel jahe kedah micakrek (don't corrupt), ipis kulit beungeut.

It is implied that the using of paribasa and babasan are not something new for the students. It is something to confess also that the value impementation in their 
daily life is not easy and need a long term observation. In spite of that, in 3-4 months of research, there were some students' behaviors that showed the internalization process of the values. Family, school, circles of students have became as factors that effected to the internalization process of the values. Some values of paribasa and babasan that be held by students were:

a values of self motivation, as a student for example, seperti bodo alewoh, ewuh elmu panungtungan, elmu tungtut, dunya siar, sukan-sukan sakadarna, cikaracak ninggang batu laun-laun jadi legok

b values of teenager, seperti: ulah kabawa ku sakaba-kaba, bisa lolondokan, ka hareup ngala sajeujeuh, ka tukang ngala sajeungkal, mangkok emas eusi madu, indung suku ge moal dibejaan, handap asor

c value of life: kajeun panas tonggong asal tiis beuteung, kabeureuyanmah tara ku tulang munding, tapi ku cucuk peda, halodo sataun lintis ku hujan sapoe, hambur bacot murah congcot, ulah adigung adiguna, ulah buntut kasiran

d values of religion: urang kudu jadi ujug ulah jadi lilin, omat urang kudu bisa ngaji diri

\section{Conslusion}

History learning can lengthen critical thinking and creativity of a nation to face the challenges in modern era. The most popular value in history learning is about the culture values. Value in education is a counseling process by making an education model that based on life values inculcation which contain value of religion, culture, ethic, and esthetic; toward personality forming who has spiritual quotient, self-controlling, holistic personality, good morals, and skills that needed by themselves, and by the society, and country. Value education as a part of the integral education activity, generally, is a conscious effort to help the students to know, realize, appreciate, and understand the values on human behavior that should be used as life guidance for them and in the society.

History learning is seen as value education, so the expectation of value that would be achieved in gradual process. That process happened in some phases like, knowing the values, reflecting the values so it could be understood also, processed, choosen, and received. There were five steps as the goals and principles on social science education: (1) understanding the values and morals to be developed to students, (2) appreciating the values and morals, (3) self-identification with those values and morals, (4) implementation $n$ daily life, (5) forming the values and morals as the new habbit for the students.

One kind of values that could be internalized to students in history learning is Sundanese local wisdom in a form of oral literature (folklore). Those traditional idioms contain so many teachings, counseling, and norms that happen in the society. One of the traditional oral expressions in society is paribasa and babasan Sunda. In etnopedagogy perspective, local wisdom such as paribasa and babasan can become a source of learning innovation that can be used; including empowered to address a variety of issues contained in the lesson

The values in paribasa and babasan that used by Sundanese society, especially on Cireundeu Cultural Village could be 
formed as a slogan, counsel, or idiom that spread mouth to mouth. Then by direct and indirect, it can be made as a guidance or measure to evaluate some acts or behaviors that occur on society or bureaucracy. Paribasa shows us warnings about what should not do something that is not commendable or pose a dangerous, and suggest things that should be done by people. Paribasa and babasan reflects good values in Sundanese belief, those are istikomah, faithful, humble, interpersonal ability, responsible, and negative values as treasonous, arrogant, pond of fighting, talk without content, spiteful, pleased with the misfortune of others, and other shameless

The value essence of Sundanese culture is striving to have life and its relation with God, humankind, and environment. Sundanese belief in God is one and we ourselves are only as a very small part in this universe. The characteristics that should be owned by Sundanese people are polite, simple, brave, honest, consistent in truth and justice, nice, trustful, respect to the other, beware, has self-controlling, fair, wide-minded, and loyal the nation and country. []

\section{REFERENCES}

Bungin, B. (2008). Metodologi Penelitian Kualitatif. Jakarta: RajaGrafindo

Carr, E.H. (1961). What Is History. New York: Penguin Book

Dixon, R. L. (2000). Sejarah suku Sunda. VERITAS, Oktober 2000 1(2) 203213.

Djahiri, H.A.K. (1990). Menulusuri Dunia Afektif: Lab.PPKN UPI.

Ekadjati, E. (2009). Kebudayaan Sunda:

Suatu Pendekatan Sejarah. Jakarta: Pustaka Jaya
El Mubarok, Z. (2008). Membumikan Pendidikan Nilai: Mengumpulkan yang Terserak, Menyambung yang Terputus, dan Menyatukan yang Tercerai. Bandung: Alfabeta

Frazer, J.G. (1932). The magic art and evolution of king, 2 vol. London: Routledge \& Kegan paul

Fraenkel, J. R. (1977). How to Teach About Value: An Analytic Approach. New Jersey: Prentice-Hall, inc

Fraenkel, J, and Wallen Norman. (1993). How to Design and Evaluate Research in Education. New York: Mcgraw-Hill. inc.

Geertz, c. (1973). The Interpretation of Cultures: Selected Essay. New York: Basic Books.

Given, B. K. (2002). Brain Based Teaching. Bandung: Kaifa.

Gottschalk, L. (1985). Mengerti Sejarah. Jakarta. UI Press

Haviland, W. A. (1999). Antropologi, Jilid 1. Translate by R.G. Soekadijo. Jakarta: Erlangga.

Hakam, K. A. (2000). Pendidikan Nilai. Bandung: CV Maulana

Hasan, S.H. (1996). Pendidikan Ilmu Sosial . Jakarta: Dirjendikti, Depdikbud Republik Indonesia.

Isjoni. (2007). Pembelajaran Sejarah pada Satuan Pendidikan. Alfabeta: Bandung.

Koentjaraningrat. (1990). Sejarah Teori Antropologi, Jilid 2. Jakarta: Universitas Indonesia Press.

Koentjaraningrat. (1987). Sejarah Teori Antropologi, Jilid 1. Jakarta: Univesitas Indonesia Press.

Koentjaraningrat. (1981). Pengantar Ilmu Antropologi. Jakarta: Rineka Cipta .

Levi-Strauss, C. (1963). Structural Anthropology. New York: Rinehart. 
Lee, P.J. (1984). Learning History. Liverpool (Britain): Heineman Educational Book

Koentjaraningrat. (2004). Manusia dan Kebudayaan di Indonesia. Jakarta: Djambatan

Malinowski, B. (1944). The Dynamic Of Culture Change: An Inquiry Into Race Relation In Africa. New Haven: Yale University Press.

Martorella, P. H. (1985). Elementary Social Studies: Developing Reflective, Competent and Concerned Citizens. Boston, Toronto: Little, Brown and Company

Mulyana, R. (2004). Mengartikulasikan Pendidikan Nilai. Bandung: Alfabeta

Muhsin, M. Penyebaran Islam di Jawa Barat. Tersedia [online] : http:// pustaka.unpad.ac.id/archives/110783/ [ 30 Oktober 2012].

Munir, A. (2007). Spiritual Teaching: Agar Guru Senantiasa Mencintai Pekerjaannya dan Anak Didiknya. Yogyakarta. Pustaka Insan Madani

Nasikun. (2011). Sistem Sosial Indonesia. Jakarta : Rajawali Pers

Nn. (2011). Kebangkitan Lokal Menjawab Tantangan Globalisasi :Revitalisasi Nilai-Nilai Budaya Sunda Bagi Penciptaan Local Good Governance Di Jawa Barat. [Online]. Tersedia: http:// ebookbrowse.com/gdoc.php?id=14623 6920\&url=ed54d7c38a9f9806b37bcb7 1aod33f8d. [28 Oktober 2012].

Nn. (2011). Kebangkitan Lokal Menjawab Tantangan Globalisasi :Revitalisasi Nilai-Nilai Budaya Sunda Bagi Penciptaan Local Good Governance Di Jawa Barat. [Online]. Tersedia: http://repository.upi.edu/operator/ upload/s_bp_054481_chapter2.pdf. [28 Oktober 2012]
Nn. (2011). Model Penanaman Nilai-Nilai Kearifan Lokal (Local Genius) Pada Masyarakat Sunda Dalam Membentuk Perilaku Lingkungan Bertanggung Jawab. [Online]. Tersedia: http:// penelitian.lppm.upi.edu/detil/1441/ model-penanaman-nilai-nilaikearifan-lokal-\%28local-genius\%29pada-masyarakat-sunda-dalammembentuk-perilaku-lingkunganbertanggung-jawab-[28 Oktober 2012].

Nn. (2011). Sekilas Pengaruh Islam Terhadap Budaya Sunda. [Online]. Tersedia: http://file.upi.edu/ Direktori/FPIPS/JUR._PEND._ GEOGRAFI/196103231986031-R._ GURNIWAN_KAMIL_PASYA/SMI-3. pdf. [28 Oktober 2012].

Pelly, U dan Asih Menanti. (1994). Teori-Teori Sosial Budaya. Jakarta: Direktorat Jenderal Pendidikan Tinggi - Departemen Pendidikan dan Kebudayaan

Rosidi, A. (2005). Pandangan Hidup Orang Sunda Seperti dalam Paribasa. Bandung: Kaki Langit

Romli, U dkk. (2011). UngkapanUngkapan Tradisional Jawa Barat. Dinas Parawisata dan Kebudayaan Jabar

Sharma, S.K. (2008). Teaching of History. New Delhi: Lotus Press

Soedjatmoko (1976) "Kesadaran Sejarah dan Pembangunan” dalam Prisma, 7, Jakarta: LP3ES.

Soedjatmoko. (1995) "Sejarah Indonesia dan Zamannya” in Soedjatmoko (Ed), Historiografi Indonesia: Sebuah Pengantar. Jakarta: PT Gramedia.

Soekanto, S. (2007). Sosiologi Suatu Pengantar. Jakarta : PT. RajaGrafindo Persada 
Sumantri, E dan Sofyan Sauri (2007). Veegers, K.J., (1993). Realitas Sosial; Pendidikan nilai Kontemporer. Refleksi Filsafat Sosial atas Hubungan Bandung: Citra Praya Individu Masyarakat dalam Soekanto, S.(1993). Kamus Sosiologi, Edisi $\quad$ Cakrawala Sejarah Sosiologi. Jakarta: Baru. Jakarta: Pt Rajagrafindo. Gramedia Pustaka Utama.

Supardan,D.(2004).PembelajaranSejarah BerbasisPendekatanMultikulturaldan Perspektif Sejarah Lokal, Nasional, Global, untuk Integrasi Bangsa (Studi Kuasi Eksperimentl Terhadap Siswa SMU Di Kota Bandung). Disertasi doktor, UPI Bandung.

Supardan, D, (2007). Pengantar Ilmu Sosial. Jakarta: Rineka Cipta

Unpad. (2012). Sosialisasi dan Enkulturasi Tradisi Penganut Madraisme Dalam Keluarga Di Kampung Cireundeu. Kota Cimahi. [Online]. Tersedia: Http: / / Pustaka.Unpad.Ac.Id/ Archives/123282/ [30 Oktober 2012]

Wahid, M. (2010). Sunda Wiwitan: Agama Penjaga Alam Lindung di Desa Kanekes Banten. Disampaikan dalam Annual Conference on Islamic Studies (ACIS) Ke - 10 pada Banjarmasin, 1 - 4 November 2010.

Wiriaatmadja, R. (2003). Pendidikan Sejarah di Indonesia Perspektif Lokal, Nasional, dan Global. Bandung: Historia Utama Press

Williams, R, (1983) Keyword, London: Fontana. 